\title{
MEMÓRIA E UTOPIA NA CENA TEATRAL
}

A estreita relação do teatro com a memória é evidente no trabalho dos atores. Sem ela os intérpretes não poderiam representar e se inventar como "outros". Ela está presente também quando o texto dramático escrito apoia-se na transmutação da memória dos autores, como é o caso dos dramaturgos que selecionamos para a análise: Jorge Andrade (1922-1980) e Gianfrancesco Guarnieri (1934-2006). Para dar pulso cênico à reminiscência de Jorge Andrade, nas peças A moratória (1955) e Rastro atrás (1966); ou ao invento como projeção imaginada da utopia partilhada pela geração de Guarnieri, em Eles não usam black-tie (1958), ambos os autores utilizaram uma das técnicas do trabalho da memória: fixaram lugares e objetos para desvelá-la (Yates, 2007: 11). Nas peças de Jorge Andrade examinadas a seguir, a lembrança objetivada do descenso social de sua família impregna tanto a fala dos personagens quanto os objetos que os cercam. Antes de tudo, as casas que habitam: a do pretérito, da opulência e do mando; a do presente, modesta e sem brilho. Mas ela também se condensa na máquina de costura, que serviu de recreio à menina rica do passado e de esteio da família no descenso do presente; no relógio pendurado na sala de jantar; nos santos nas paredes. Atando significados simbólicos e relações sociais, a casa e os objetos são mais que peças de cenário. Neles se inscreve a história social da família, que é também a da classe a que pertenceu o dramaturgo: a oligarquia agrária ligada ao café.

Em Eles não usam black-tie, o título da peça de Guarnieri alude à indumentária de gala dos espectadores que frequentavam a companhia de maior projeção no período, o paulistano Teatro Brasileiro de Comédia, inaugurado em 1948. No traje de festa sobressaiam as insígnias vistosas da ostentação burguesa, rechaçada pelo público jovem, levemente desalinhado e afinado com o polo mais à esquerda do campo teatral. Sucesso estrondoso, a peça ficou um ano em cartaz, garantiu uma sobrevida inesperada ao Teatro de Arena, alimentou os sonhos de uma geração sobre o potencial da cultura na transformação e reordenação das relações sociais. Por seu intermédio a classe operária entrou pela primeira vez nos palcos da metrópole, na pegada forte do drama de uma 
família tensionada pela greve, pelo conflito de gerações e pela luta de classes. Para dar verossimilhança à experiência social de uma classe que não era a sua, Guarnieri mesclou o imaginário de sua geração, alimentado pela militância política no Partido Comunista, à memória por procuração. E, como Jorge Andrade, fixou a lembrança imaginada em suportes expressivos: no morro carioca, na casa, nos móveis, na dicção dos personagens. Que ambos tenham se valido das relações familiares, materializadas em lugares e objetos, para dar forma a experiências sociais mais amplas, num período em que o teatro tinha uma importância cultural e política incontestável, ${ }^{1}$ é um indicador eloquente da intuição dos dramaturgos de que casas e relações perpassadas pela linguagem do parentesco são um microcosmo do mundo social onde se ventilam emoções represadas de molde a suscitar a entrega comovida da plateia - tal como dá a ver a literatura sociológica e antropológica de maior fôlego sobre o assunto. ${ }^{2}$

A cultura brasileira, nessa época, vivia uma conjuntura excepcional de transformação, sinalizada pelo cinema novo em gestação e pelo intrincado entrelaçamento do teatro com o rádio e com o início da televisão brasileira. A afirmação da cena teatral moderna foi marcada não só por novos modos de conceber o repertório e o trabalho dos atores, atrizes, diretores e cenógrafos, como pelo recado político e social dos grandes dramaturgos brasileiros da época. Jorge Andrade, Gianfrancesco Guarnieri e Nelson Rodrigues, entre os principais, ajudaram a converter o teatro em suporte de uma renovação radical na maneira de apreender a experiência contemporânea da sociedade brasileira. Suas peças dramatizavam conflitos sociais lancinantes - o declínio das elites rurais, as vicissitudes dos setores médios, o impacto da vida urbana nos costumes e nas relações familiares, a experiência da classe operária, a ascensão dos imigrantes. Nesse contexto, o palco, os diretores e os intérpretes tornaram-se os protagonistas de uma cultura cênica que foi o retrato do país no momento crucial de crise de uma velha ordem e arranque para uma nova etapa de expansão econômica e social.

Arte social, arte coletiva, arte da representação, o teatro encenado em São Paulo nesse período é inseparável da vida urbana, da sociabilidade multifacetada, da circulação em escala internacional promovida pela imigração em massa de trabalhadores entre 1880 e 1920, pela vinda de estrangeiros educados, professores e diretores de teatro, ao longo dos anos de 1930 e 1940 . Laboratório voluntário e compulsório dos sonhos acalentados pela elite paulista e pelos setores médios, o teatro deu forma a assuntos que pulsavam e antecipou comportamentos que se tornariam emblemáticos no futuro. Por conseguinte, não é aleatório que a sociedade encenada no palco encontrasse ressonância na sociedade real do público. ${ }^{3}$ 


\section{JORGE ANDRADE: O TRABALHO DA MEMÓRIA}

A expressão, corrente entre os estudiosos, alude à matéria-prima da dramaturgia de Jorge Andrade e à carpintaria necessária para levá-la aos palcos. Da memória individual à memória grupal, a obra de Jorge Andrade ${ }^{4}$ constrói um "painel de quatrocentos anos da História do Brasil", perpassado pela "busca do pai perdido, os bens e o sangue”, na definição de Sábato Magaldi (1986: 672). A abrangência temporal enlaça o conjunto de temas abordados em linguagem teatral: os ciclos dos bandeirantes e da industrialização da metrópole paulista, a ascensão do imigrante, "as energias urbanas fermentando e desgastando a velha ordem agrária” (Morse, 1986: 645), os conflitos de geração e de classe. Daí o interesse suscitado por sua obra, maior até entre os historiadores e cientistas sociais do que entre os estudiosos da dramaturgia e da literatura, se o metro utilizado for o da publicação de estudos recentes sobre ele. ${ }^{5}$

Neto de fazendeiros do interior de São Paulo, nascido em 1922 em Barretos, Jorge Andrade não seguiu o destino traçado para os homens de sua classe social. A crise econômica de 1929 foi precedida por uma socialização diversa daquela que conformava o aprendizado masculino do mando. O duplo deslocamento, econômico e de gênero, experimentado desde muito cedo, enfeixa sua memória e reponta na dramaturgia. O sentimento de uma prontidão masculina, a um só tempo indesejada e inalcançável, que sombreara os primeiros anos de vida, converteu-se, aos sete, na certeza de um mundo perdido. ${ }^{6}$

A mãe, de mãos “delicadas como asas de borboleta” (Andrade, 2009: 25), sempre pronta a lhe infundir confiança, dividiu os cuidados com o filho com a parentela feminina que habitava a casa da fazenda: a avó materna e as tias ainda solteiras. A intimidade com o universo feminino revela-se no gosto pela leitura e nas brincadeiras. Algumas delas causavam aversão ao pai e indignação no avô. Em uma das estripulias do neto, ele o manteve suspenso no ar "pelas orelhas", enquanto o arrancava dos sapatos de salto alto emprestados por uma das tias para compor o personagem um tanto estranho de marido. ${ }^{7} \mathrm{O}$ castigo, vivido como uma distinção que alimentou o orgulho do menino e ampliou o amor que sentia pelo avô, produziu um sentimento bem diverso da solidão indefesa que experimentava diante do pai.

Aferrado aos valores masculinos rígidos que governavam o mundo dos fazendeiros paulistas, o pai ausentava-se com frequência e encontrava na caça mais que passatempo dileto. Caça e masculinidade eram uma coisa só, como bem percebeu o filho ainda menino. Não só pela observação das ausências prolongadas do pai, mas por suas reações às coisas que fascinavam Jorge Andrade, em tudo contrárias às dele: das brincadeiras às leituras e, mais tarde, quando homem feito, da profissão que escolhera - escritor de teatro.

A imagem do pai "escondendo-se, nas caçadas", da "vergonha" trazida pelo filho, ficou grudada na memória de Jorge Andrade, antes de ganhar forma 
dramática, muitos anos depois da crise de 1929 que arruinou famílias da elite agrária ligada ao café, entre elas, a dele.

A notícia da catástrofe que se abatera sobre a família ele recebeu aos sete anos e só compreendeu aos poucos. Mas a expressão de cólera, de medo, de angústia, de quase loucura, ele percebeu de imediato nos olhos e no comportamento inusitado do avô materno que ele adorava. Sempre tão seguro e enérgico, o avô passou a falar sozinho como louco, esbravejando no meio das jabuticabeiras. Que algo terrível estava no ar, o neto sentiu pelo desaparecimento das tias e pela permanência da avó na cozinha, "na beira dos tachos, como se fizesse provisões para uma longa viagem" (Andrade, 2009: 78). Ninguém olhava o avô de frente. A mãe, sempre tão solícita, mal lhe dava boa noite. Pela primeira vez na vida, o menino ouviu choro nos quartos. A descoberta de "que gente grande chorava" foi acompanhada pela sensação de desproteção. E, conforme avançava a ruína da família, pelo sentimento de solidão.

Petrificado, Jorge Andrade assistiu ao avô vituperar contra um inimigo invisível, com a espingarda na mão e o rosto congestionado. A barba branca parecia "negra como o ódio, os olhos bondosos viraram espreita maligna, tocaia. [A] avó, de joelhos, abraçada às pernas dele, paralisava os movimentos assassinos. [A] mãe, agarrada à espingarda era um anjo lutando", enquanto o avô cuspia as palavras como arma: - "Não entregarei minhas terras por nada. Pode dizer a eles [os credores], na cidade, que se vierem aqui eu os receberei a bala, a bala! Está ouvindo?" (Andrade, 2009: 79) .

A altivez do enfrentamento imaginário, arrefecida pela intervenção da avó e da mãe, deu lugar ao desespero sem ação. Caído e ajoelhado, o avô suplicava para que não lhe tirassem as terras dos antepassados e dos filhos, a fazenda que dava colorido e sentido à vida. "Os sete anos do neto transformam-se em setenta e ficaram para sempre iluminados pela luz colorida das bandeiras, marmorizados na sua Pietá fazendeira" (Andrade, 2009: 79). A derrocada do mundo do avô e a ruína econômica e social da família, tão entranhadas nele, serão um dos esteios da dramaturgia de Jorge Andrade. Quinze anos depois e já adulto, instalado na cidade de São Paulo, para onde se mudara com o propósito de cursar direito, ele usará o episódio narrado acima em A moratória.

Escrita em 1954 e levada à cena no ano seguinte, a peça foi concebida em meio à decisão de abandonar a faculdade para dar chão ao fascínio pelo palco. O teatro ele descobriu primeiro como espectador assíduo da companhia paulista mais importante na virada dos anos de 1940, o Teatro Brasileiro de Comédia, e, depois, como aluno da Escola de Arte Dramática, entre 1951 e 1954. Nela iniciou-se nas manhas da dramaturgia e aprimorou a linguagem teatral. Premiado, em 1954, como autor revelação, pelo texto O telescópio, foi com A moratória que seu nome se firmou no rol da melhor dramaturgia brasileira e se associou à linguagem moderna que estava sendo gestada em São Paulo no teatro, nas artes plásticas e nas ciências sociais (Arruda, 2001). 
Pela mescla de condições objetivas e subjetivas, o contexto era propício para o sonho de Jorge Andrade de fazer da dramaturgia uma profissão. Entre as condições objetivas, sobressaem os novos espaços de sociabilidade e de profissionalização que se abriam em São Paulo e as alterações que se produziam em passo acelerado na estrutura social e demográfica da cidade. Em menos de três décadas, a população de São Paulo quintuplicara, passando dos 579 mil, cifra registrada m 1920, para 2,198 milhões de habitantes na década de 1950. A cidade, "explodindo em número de habitantes, quebrava a sua velha carapaça quatrocentona, internacionalizando-se", ${ }^{8}$ nas palavras Décio de Almeida Prado (1917-2000). A percepção do mais destacado crítico de teatro do período é compartilhada pela companheira de juventude ${ }^{9}$ e colega de faculdade, Gilda de Mello e Souza (1919-2005).

Ao mesmo que tempo que a ordem antiga se rompia, a urbanização se processava de maneira acelerada. A decadência de todo um setor da sociedade [a oligarquia agrária] era compensada pelo desenvolvimento de outro e a perda de prestígio do fazendeiro se cruzava com a ascensão econômica e social do imigrante. Presenciava-se, sem fôlego, uma substituição simétrica de estilos de vida e não o lento desaparecimento de um mundo cuja agonia se pudesse acompanhar com lucidez (Mello e Souza, 1980: 110).

A consequência disso era a crença partilhada no futuro e não a percepção dilacerada de um universo social fenecente, tal como desvelado pelos romancistas nordestinos. A retradução da experiência social no plano formal da linguagem se deu em São Paulo pela dramaturgia e pelas ciências sociais e não pelo romance. Paradoxalmente mais "moderna" e mais "provinciana" que o Rio de Janeiro - então capital federal do país - São Paulo se tornou o polo modernizador do teatro brasileiro. ${ }^{10} \mathrm{~A}$ estreita relação entre o teatro, a universidade e a cidade é um dos indicadores do grau de complexidade do sistema cultural paulista. A ampliação do perfil social de recrutamento dos envolvidos com a atividade teatral e intelectual, a montagem de instituições afinadas com os ideários artísticos e científicos de ponta na época, a presença de estrangeiros, professores e diretores, tudo isso, somado, foi decisivo para a implantação de novas modalidades de trabalho intelectual, entre elas, a dramaturgia.

Aplicadas à trajetória acidentada de Jorge Andrade, tais condições objetivas explicam o desvio de percurso, do direito ao teatro. Desta feita de maneira deliberada e não como resultado do solapamento do destino social de sua família em virtude da crise econômica, matéria-prima de seu teatro. Sua dramaturgia "exprime um modo de preservar o passado, uma forma de cristalizar a origem. Mas expressa, de outro lado, distanciamento do anteriormente vivido" (Arruda, 2001: 153).

Tal reelaboração implicou um corpo a corpo com as fraturas do passado - de sua família e de sua classe. O registro deste enfrentamento encontra-se numa das frases mais citadas de Jorge Andrade pelos estudiosos de sua obra. A recorrência é proporcional à acuidade da observação do dramaturgo sobre os motivos recônditos que o levaram à ficção e ao teatro. 


\begin{abstract}
- Há pessoas que fazem psicanálise deitadas em sofá, pagando uma nota. Eu faço comigo, de graça, descendo a ladeira. E a verdade estampa-se inteira dentro de mim: eu fiz psicanálise, criando personagens que foram viver, no palco, os fantasmas que me atormentavam. Personagens que contam a história da minha vida - cheia de momentos felizes e também de vergonha. Há muitas coisas em minha vida pedindo explicações. De muitas, lembro-me bem. Mas são as escondidas que nos atormentam, as que ficam perdidas não sei em que imobilidade, agarradas às paredes como hera, guardadas em fundo de gavetas de cômodas velhas, refletidas em caixilhos, esquecidas em álbuns fotográficos, escondidas dentro de nós (Andrade, 2009: 171).
\end{abstract}

Não fosse a escrita e o teatro, e essas coisas escondidas dentro de nós e perdidas em sua imobilidade - que são o sal e o sol da vida, pela mistura de tormento e alegria, que impulsiona para a frente quando encontra suporte, ou paralisa e até mesmo enlouquece na falta dele - teriam ficado guardadas na memória do dramaturgo. A ideia de que "todas as famílias felizes se parecem, cada família infeliz é infeliz à sua maneira" (Tolstói, [1878] 2009: 17) encontra sua contrapartida em A moratória. O avô adorado de Jorge Andrade é convertido no personagem trágico da peça, Joaquim, que dá tônus e verossimilhança à derrocada da família.

Graças ao encontro do dramaturgo em início de carreira, da jovem atriz em ascensão, Fernanda Montenegro, e do diretor experiente, Gianni Ratto (19162005), o público paulista que frequentava o teatro nos anos de 1950 pôde ver no palco a experiência objetivada da oligarquia agrária, arruinada pela crise de 1929 e pela incapacidade de reinventar-se no descenso e na cidade. Sensível ao que de mais importante estava despontando na dramaturgia paulista, o italiano Gianni Ratto, em menos de um ano de residência no Brasil, fez na capital paulista o mesmo que o polonês Ziembinski (1908-1978) fizera em 1943, no Rio de Janeiro, dois anos depois de fixar residência no país, ao dirigir a peça Vestido de noiva, de Nelson Rodrigues. Ambos mostraram que a consolidação do teatro moderno no país dependia do autor brasileiro.

Por sugestão de Décio de Almeida Prado, Gianni Ratto leu A moratória e encontrou o dramaturgo que precisava para pôr à prova suas concepções como diretor e cenógrafo. O título da peça alude à "dilatação do prazo pelo credor ao devedor para pagamento de uma dívida". ${ }^{11}$ Se a dívida não for saldada, a propriedade que serviu de caução é repassada como forma de pagamento. Tal como aconteceu com a fazenda do avô, vencida a moratória, ela não voltou mais ao seu comando. A perda da propriedade, concomitante à perda de sentido da vida do avô, selou o destino de rebaixamento social da família.

Encenada pela Cia. Maria Della Costa em 1955, A moratória foi um marco no teatro da metrópole. Revelando um "autor prisioneiro do espaço e do tempo perdido da fazenda" (Mello e Souza, 1980: 115), a peça dá forma às personagens que ele inventou por meio de traços condensados dos membros da família. Especialmente dos que singularizavam o avô materno. No papel de Joaquim, suas falas no momento do anúncio da moratória e da descoberta da 
falência material e social que recairia sobre ele e toda família são idênticas às registradas pelo autor em Labirinto, misto de memória e autobiografia. ${ }^{12}$

Antes de serem caracterizados com os traços da psicologia individual, os personagens são "o Pai, a Mãe, o Filho, a Filha; e os atos, pensamentos e desejos que deles derivam, ligam-se menos à história isolada de cada um do que à história da propriedade a que pertencem. É a perda da fazenda que explica a revolta do pai, o fracasso do filho, a crispação subterrânea da filha, a desencantada abnegação da mãe" (Mello e Souza, 1980: 114). O vigor do texto foi reforçado pela interpretação de Fernanda Montenegro, que infundiu verossimilhança e verdade cênica em voltagem máxima à protagonista da peça. No papel de Lucília, a "única personagem da família de fazendeiros que abandona a lamúria pela fortuna perdida e enfrenta com decisão a realidade" (Magaldi, 1986: 650), ela ganhou a plateia e a crítica. Realista e avessa ao exercício complacente do autoengano, empenhada na sobrevivência da família com o auxílio da máquina de costura que lhe serviu de hobby quando menina rica e bem-vestida, e que, no momento do descenso, tornou-se a fonte de sustento da família, Lucília expõe sem meios-tons a ruína que dilacera a todos. Lucília, a filha de uma família de elite arruinada, ao ser encarnada pela atriz, filha de operários, alçou Fernanda a uma posição destacada na hierarquia das grandes intérpretes da época.

A peça mostra a habilidade do dramaturgo para justapor no palco o passado e o presente. Segundo o crítico Sábato Magaldi, professor do dramaturgo na Escola de Arte Dramática, a perícia reside na maneira como ele joga com os "planos do presente (1932) e do passado (1923)", de tal forma que o segundo não se converte em "mero flashback ilustrador do drama final. A maestria técnica é tão admirável que, na dinâmica do texto, frequentemente um episódio de 1932 parece preparar o que ocorreu em 1929" (Magaldi, 1986: 673). À solução narrativa somou-se a habilidade de Gianni Ratto, que dividiu o cenário em duas partes expostas em diagonal. Uma delas correspondia à opulenta fazenda de café de 1929; a outra, à modesta casa na cidade do presente, em 1932, sugerindo, assim, "a paralisação do tempo numa realidade superior e esmagadora” (Magaldi, 1986: 673).

O domínio técnico do cenário fazia pulsar a realidade social que o dramaturgo estampara no texto e que o diretor ajudou os intérpretes a corporificar no palco. Quem melhor captou essa transmutação da experiência social de Jorge Andrade em linguagem teatral foi Décio de Almeida Prado. Ligados que eram por laços de parentesco que se convertem numa "espécie de ficção social, ambos foram criados 'dentro de idêntica paisagem social'” (Prado, 1986: 625), representada pela vida das elites agrárias nas fazendas: espaço do mando, da moradia e da sociabilidade. Décio, de longe e de passagem, nas férias escolares, quando voltava à fazenda da família materna; Jorge Andrade, de perto e de dentro, "entranhadamente imerso nessa realidade humana que 
viria, mais tarde, a constituir o seu território literário de eleição como autor de teatro" (Prado, 1986: 626).

Justapondo o passado e o presente e, ao mesmo tempo, a ambiência social retratada nos dois cenários, a peça expõe o dilaceramento da família, evitando a solução fácil da narrativa cronológica. O espectador, sabendo mais que os personagens, sobre o destino social que os espera, compreende, antes deles, as marcas e os sofrimentos impressos pela transição e declínio do universo em que se movimentam. A observação de Décio de Almeida Prado, aludindo ao esforço de objetivação do dramaturgo em relação ao mundo social que foi o dele e é o de suas personagens, ganha registro sociológico na análise de Maria Arminda do Nascimento Arruda.

O tempo objetivo de declínio da sociedade agrária coabita o movimento de subjetividade das personagens, lançadas em contextos que solapam e negam o que parecia inscrito nos seus destinos sociais. Posta ao lado das figuras identificadas com a sociedade urbano-industrial, a dramaturgia [de Jorge Andrade] reproduz essa história em dilaceramento, de onde retirou a matéria viva de seu teatro, testemunho pungente de um mundo fenecente e de outro em ascensão (Arruda, 2001: 137).

Em 1966, onze anos depois da primeira montagem de A moratória, Gianni Ratto levou ao palco carioca Rastro atrás, encenada pelo Teatro Nacional de Comédia. Nela diluem-se as fronteiras entre reminiscência e autobiografia. Acerto de contas com o passado e ceticismo em relação às potencialidades do presente, Rastro atrás no sentido literal significa a inesperada mudança de direção da caça. Em vez de seguir em frente, ela finge voltar atrás e deixa o rastro marcado para confundir o caçador.

No sentido metafórico, caça e caçador são o pai e o filho, os protagonistas, em quatro momentos entre 1922 e 1965, mediados pelas tias, pela avó paterna, pela lembrança da mãe morta. Ao longo da peça, Vicente é menino, adolescente, jovem e adulto. Sem qualquer preocupação com a linearidade cronológica, o menino de cinco anos cede lugar ao homem feito de 43 anos, dramaturgo reconhecido, casado com Lavínia, pai de um garoto, às voltas com vicissitudes enfrentadas pelo escritor de teatro, prensado entre o ganha-pão como professor de ginásio, a oferta tentadora da televisão, a recusa em ceder ao gosto fácil do público. Na mesma cena, Vicente volta aos 23 anos, prestes a largar a casa da família, a noiva e a cidade do interior parada, modorrenta e sem perspectiva, para se reinventar na metrópole. A urdidura da trama se nutre pelos desvãos da memória atormentada de Vicente em relação ao pai.

A ferocidade dos diálogos, proporcional à exasperação e à culpa entranhadas pela relação dilacerada, culmina no afastamento definitivo de ambos. Vicente vai para a cidade, o pai se refugia na mata, na companhia de um antigo empregado, e retira da caça o sentido da vida. Antes de fugir da casa do pai, Vicente dá a estocada final, ao afirmar que vai vencer e provar que é alguém sem nada dele, inclusive o sobrenome que ele não usará mais. 
Mas isso o espectador só fica sabendo no final da peça. A alternância de idades da primeira parte é replicada na segunda. O corte narrativo é dado pela volta de Vicente à casa paterna, aguardado pelas tias solteironas sem futuro, agarradas às lembranças e às mágoas do passado. Etelvina, uma delas, após a recepção calorosa do sobrinho renomado na capital, interpela-o para saber o que ele veio procurar depois de vinte anos de ausência:

- Você bem disse - prossegue Etelvina - fizemos um saque contra a morte. Foi o que nos restou de tudo. Moramos numa casa, comemos em louças e bebemos em cristais que já não nos pertencem. Só temos o corpo, nossos vestidos de filhas de Maria, livros de missa, santinhos e os caminhos da igreja e do cemitério. Foi só isso que você e seu pai nos deixaram. Consumiu-se tudo numa incompreensão odienta. A sua verdade! A sua verdade é a nossa agonia. É tudo e todos desta casa. Você fez de sua inclinação [referência à profissão de Vicente) o mesmo que seu pai, das caçadas: um meio de fugir, para um mundo só de vocês (Andrade, 1986: 491).

No final da peça, pai e filho se reconciliam. Esmagados pela culpa e pelo remorso, ambos se procuram. Os repertórios são distintos, mas a busca é semelhante. Com o telegrama na mão que comunica a volta do filho, o pai anuncia para o empregado que sempre o acompanha na caça, que Vicente ficou famoso, viajou para o estrangeiro e virou escritor, coisa distinta de artista, pois "ninguém precisa pintar a cara para escrever". O filho podia agora "gostar do que quisesse. A gente ser atrasado é uma infelicidade, compadre" (Andrade, 1986: 525). Diante do filho, que corre para vê-lo, o pai pergunta: "como vai o grande homem? Bem - responde o filho - e o senhor"? Os dois se examinam com esforço e o pai retruca: "Eu não sabia. Eu não... podia compreender meu filho!" (Andrade, 1986: 525).

A observação embargada sinaliza mais que um reencontro; o único diálogo de fato que tiveram na vida. Com ele dá-se o apaziguamento que atenua o remorso, a culpa e a suprema recusa que Vicente cometera contra o pai - a retirada do sobrenome. O mesmo gesto feito pelo dramaturgo quando saiu da casa paterna e fez-se reconhecido como Jorge Andrade, apagando o nome de batismo: Aluísio Jorge Andrade Franco. Mas se ele "matou o pai com as palavras, com a escrita, foi também através delas que com ele se reconciliou", mostra-nos Maria Arminda do Nascimento Arruda (2001:163).

O sucesso no teatro nunca mais foi o mesmo para Jorge Andrade depois dessa peça. Apesar da crítica favorável, a montagem de Rastro atrás restringiu-se ao circuito carioca. O conflito entre pai e filho, no registro da culpa e do remorso, não era mais capaz de eletrizar a atenção do público jovem que tomou a cena teatral da época a partir da criação do Teatro de Arena, do Oficina e dos Centros Populares de Cultura, responsáveis pela valorização do autor nacional, pela introdução de novas convenções teatrais, e por uma nova articulação entre cultura e política no domínio da dramaturgia. 
Como resultado da entrada em cena de novos grupos e de um público distinto, jovem, universitário e de esquerda, houve uma "alteração social do palco" (Schwarz, 1978: 62) e o teatro de repertório, que por quase duas décadas fora o espaço de projeção de Jorge Andrade, perdeu a centralidade que tivera até então. "Mudanças estruturais no campo artístico" - correlatas à alteração do perfil social e cultural do novo público e à sedimentação do "conceito de engajamento artístico de esquerda" (Napolitano, 2001) fizeram com que "o bom teatro, que durante anos discutira em português de escola o adultério, a liberdade, a angústia [parecesse] recuado de uma era" (Schwarz, 1978: 81).

O chute inicial nessa direção foi dado em São Paulo por um jovem de 23 anos - filho de imigrantes italianos - que viera do Rio de Janeiro para dar continuidade à militância estudantil: Gianfrancesco Guarnieri. Sua primeira peça, Eles não usam black-tie, conforme veremos a seguir, é um marco nessa reordenação do teatro encenado na metrópole, e a prova cabal de que a dramaturgia é "a forma literária mais adequada à esfera da ação e, portanto, à ética e a política” (Schorske 1993: 40).

\section{GIANFRANCESCO GUARNIERI: GESTAÇÃO DA UTOPIA}

Ao chegar na UNE, nossos colegas já haviam feito uma barricada com móveis, cadeiras em frente ao prédio. [...] Nós temos que sair daqui o mais rápido possível porque eles vão invadir a UNE... Na verdade, ali não havia comunista, no sentido literal da palavra, havia, sim, um bando de rapazes que pretendiam generosamente mudar o Brasil através do teatro, da cultura popular (depoimento do ator Carlos Vereza transcrito nas memórias de Deocélia Vianna, 1984: 171).

O núcleo de lideranças atuantes no Teatro de Arena, ${ }^{13}$ em São Paulo, entre a fundação, em 1953, e o fechamento, em 1964, acuado pelo regime militar, juntou jovens profissionais egressos da Escola de Arte Dramática de São Paulo (o diretor, ator e autor José Renato ${ }^{14}$ ) e de estágios de formação no exterior ( $\mathrm{Au}$ gusto Boal), a talentosos rapazes e moças atuantes em teatro amador, socializados em sua maioria em famílias de ativistas de esquerda. O Arena aglutinou um punhado de gente inovadora, treinada para exercer o ofício teatral, sem prévia experiência política, e a turma do Teatro Paulista do Estudante criado em 1955, braço cultural da militância comunista no movimento estudantil. Verdadeiros coringas, uns e outros estavam dispostos a exercer as principais atividades na divisão do trabalho imperante no teatro profissional do período: atores, encenadores, autores e empresários. Tiveram de lidar com essa "vocação", de encargos tão variados, em momento privilegiado de mudança no arcabouço institucional do teatro profissional no país, sem poder contar com o volume de recursos que viabilizara o mais bem-sucedido empreendimento na cena paulistana, o Teatro Brasileiro de Comédia. 
A despeito de tais limitações, os maiores desafios enfrentados pelo pessoal do Teatro de Arena tinham como referência o modelo de excelência do chamado teatro burguês. O espaço em arena fora em parte determinado pelo acanhamento do prédio sede da trupe, mas era também uma alternativa promissora de arriscar experimentos cênicos fora do palco italiano. O ecletismo do repertório nos primeiros anos - mesclando comediógrafos medianos (Achard, Puget), contemporâneos provocativos (Tennessee Williams, O'Casey, Pirandello), clássicos (Molière, Martins Pena) e autores de bulevar (Mirbeau, Feydeau) - seguia de perto o receituário que vinha dando certo no TBC. Nenhum dos autores nacionais encenados no período de arrancada (José Renato, Augusto Boal, Silveira Sampaio) estourou na recepção crítica ou na bilheteria.

De início, o pessoal de esquerda parece ter se acomodado a certa rotina de sobrevivência, tentando, claro, infundir carga política em textos de denúncia social (Steinbeck). O retumbante sucesso de público e de crítica logrado pela montagem de Eles não usam black-tie (1958), de Guarnieri, alterou radicalmente o balanço de forças no interior do grupo e, no rescaldo, as prioridades: em lugar da aposta num repertório eclético encenado com surpresa em espaço de arena, o rendimento dramático e a feição estética se punham doravante a reboque do recado doutrinário.

As biografias em contraponto de Gianfrancesco Guarnieri e Oduvaldo Vianna Filho permitem restituir o universo de experiências que estão na raiz do projeto político e intelectual da geração a que pertencem. Ambos conciliaram exigências culturais contraditórias: valeram-se do manancial de recursos técnicos e da carpintaria dramática que aprenderam desde moços para trazer à cena um retrato verista e pungente das vivências de trabalhadores idealizados, com os quais pouco conviveram e sobre os quais possuíam apenas as coordenadas de existência hauridas no convívio com militantes veteranos e na literatura de esquerda.

No plano estritamente pessoal, a adoção na íntegra do modelo paterno de conjunção entre atividades profissionais de criação artística e a militância em organizações de esquerda marcou a fundo a dramaturgia de ambos. Por outro lado, convém atentar ao contexto abrangente: as circunstâncias de explosiva transformação que moldaram as mídias nascentes na incipiente indústria cultural, no eixo Rio-São Paulo. Assim como Guarnieri crescera ouvindo e assistindo a encenações de ópera, a cargo de companhias italianas de primeira, ${ }^{15}$ Vianinha logo se familiarizou com o trânsito entre os estilos dramáticos que eram as fontes de sustento da família. Filhos de artistas a braços com oportunidades e desafios timbrados pelo conjunto de mudanças que afetava a atividade cultural profissional. Herdeiros trunfados de veteranos reconhecidos na corporação artística.

Nascido em Milão, em 1934, Gianfrancesco era filho único de músicos italianos, o maestro Edoardo Guarnieri e a harpista Elsa Martinengui Guarnie- 
ri. A exemplo de tantos outros artistas europeus aqui chegados durante a Segunda Guerra, ora perseguidos por razões políticas, ora ameaçados pelo desemprego, ou movidos pela junção de tais dissabores, a mãe aceitou, em 1936, o convite para trabalhar na Orquestra Sinfônica Brasileira (RJ); em seguida, o pai foi chamado a reger. Logo o maestro se filiou à base carioca do Partido Comunista Brasileiro. Decerto influenciado pelos afazeres dos pais, Gianfrancesco teve educação diferenciada e um tanto dissonante das crianças de idêntica condição social: frequentava as matinês de ópera no Teatro Municipal carioca, as comédias nos teatros da Cinelândia e os filmes do neorrealismo italiano. Cresceu num círculo de sociabilidade que reunia artistas e profissionais ligados à atividade musical; falava italiano em casa e na escola comunitária. Fez o curso primário no Liceu francês, onde aprendeu o idioma; no secundário, estudou no Colégio Santo Antonio Maria Zacaria, tendo aí participado num grupo de teatro, para o qual redigiu uma peça aos 14 anos.

Nascido em junho de 1936, no Rio de Janeiro, Oduvaldo Vianna Filho era fruto do segundo casamento do pai, o dramaturgo Oduvaldo Vianna (18921972), com Deocélia Vianna. ${ }^{16}$ Existem indícios de vínculos com a oligarquia. $O$ avô paterno, Justiniano Vianna, ex-aluno do Colégio São Bento (o mesmo frequentado pelo pai), chefe político a mando do Partido Republicano Paulista no Brás, lograra nomear o filho para cargos públicos. O pai de Vianinha estreou em 1917, com a montagem fracassada do texto Amigos de infância, terceiro colocado num concurso carioca de comédia. Oduvaldo pai era um polígrafo experiente dos gêneros dramáticos em voga: escrevia peças de teatro, roteiros de cinema e novelas de rádio, dirigia filmes, mas garantia o ganha-pão acumulando empregos na imprensa, no rádio e na televisão, alto funcionário a serviço da rede Associadas, de Assis Chateaubriand. Até 1945, os pais de Vianinha eram simpatizantes do Partido Comunista Brasileiro (PCB) e cumpriam as tarefas inerentes a tal envolvimento, angariando donativos e organizando festas para coleta de recursos. Uma vez legalizado o partido em 1945, o casal se filiou à organização. Mesmo sem se eleger deputado estadual, a votação alcançada pelo pai lhe garantiu a suplência de Mário Schenberg. Vianinha fez o primário no colégio público Caetano de Campos e o secundário no Mackenzie.

O secundarista Gianfrancesco colaborou numa publicação da juventude comunista, o jornal Novos Rumos, fazendo entrevistas e traduções do italiano e do francês. Após ter sido aprovado no supletivo, voltou ao Franco-Brasileiro para o curso normal e de imediato se envolveu no movimento estudantil secundarista, nomeado presidente da Associação Metropolitana de Estudantes Secundários e vice-presidente da União Nacional dos Estudantes Secundários. Com a família instalada em São Paulo, desde 1953, ele chegou à cidade já ungido como secretário-geral da União Paulista dos Estudantes Secundários; militava como clandestino na Juventude Comunista, com nome de guerra, e acabou promovido pelo PCB como responsável pela formação de células. 
Após a cassação do partido por Dutra, em 1947, a casa dos Vianna se converteu em ponto de reunião dos comitês estadual e central do partido. Aos 14 anos, Vianinha ingressou na União da Juventude Comunista, cujos integrantes procediam em maioria de uma classe média instruída; aos 17 anos, matriculou-se na Faculdade de Arquitetura do Mackenzie, curso que abandonaria no terceiro ano. No ano seguinte, começou a fazer teatro amador. Guarnieri e Vianinha foram fundadores do Teatro Paulista do Estudante, com a bênção do encenador e estudioso italiano Ruggero Jacobi (Raulino, 2002). Por alguns anos, as carreiras de ambos avançaram em paralelo: casaram-se com colegas de palco (Gianfrancesco com Mariuza Vianna, prima de Vianinha; este com Vera Gertel, também filha de militantes comunistas), trabalharam como atores em sucessivas montagens do Teatro de Arena e se lançaram precocemente como autores inovadores, ${ }^{17}$ logo festejados e premiados. $O$ teatro se tornara a razão da vida afetiva e profissional.

Peça em três atos e seis quadros, Eles não usam black-tie (Guarnieri, 2001; ver também Prado, 2001) estreou em fevereiro de 1958, com direção de José Renato e produção do Teatro de Arena. Conforme testemunho do autor, ele teria escrito o texto em menos de um mês, em 1956, com apenas 21 anos. A peça e a encenação inauguram um novo ciclo do teatro brasileiro, ao introduzir no palco os conflitos de classe numa sociedade urbano-industrial em processo acelerado de expansão. O eixo da tensão dramática gira em torno do conflito geracional entre o pai operário (Otávio), convicto de sua lealdade à classe trabalhadora, e o filho (Tião) que se insurge contra as diretrizes de uma greve que lhe parece pôr em risco as expectativas de mobilidade social.

A narrativa cortante transita entre o ambiente doméstico e as vicissitudes do embate político-sindical. A greve é o estopim de um duplo enfrentamento: de um lado, entre os operários, o patronato, a polícia; de outro, o entrevero da firmeza dos pais com a contestação do filho. Enquanto a armação e o desfecho da greve alicerçam o andaime narrativo, o conflito entre pai e filho arrebenta a solidariedade do grupo e fisga a emoção do espectador. O fio desencapado da tensão em cena se escora na resistência à greve explicitada pelo filho, que enxerga aí um embaraço a um projeto de vida mais confortável. A postura do filho se fortalece, no plano cênico, pelo fato de que sua mulher (Maria) está grávida. Tal circunstância qualifica e quase justifica sua conduta fora de esquadro. O Tião, pai virtual, responsável, amoroso, como que se sobrepõe aos deveres filiais de um jovem operário já feito homem. A adesão do público às razões invocadas pelo filho encontra assim respaldo na tessitura multifacetada do conflito.

O confronto entre uma ética coletivista, comunitária, compartilhada, e uma atitude individualista, é o combustível que move tanto os mais velhos, identificados por inteiro com os de baixo, como os moços que vislumbram a chance de se livrar das servidões da classe operária. Na verdade, o desfecho 
dilacerante do enfrentamento não salva ninguém e faz os protagonistas pagarem de algum modo. A intolerância paterna sinaliza a rigidez da integridade e a insubordinação filial traz respiro a constrições até então mandatórias. Instado a sair de casa e dar provas de irrestrita adesão àquele microcosmo antes de poder ser readmitido aos seus - os pais, os amigos e a mulher -, o sacrifício do filho desarruma expectativas de correção política e incendeia o coração da plateia. Não fora tamanho desacerto de conduta, não haveria salvação fora do destino coletivo. O projeto de mobilidade está condenado à solidão e ao rechaço dos iguais, mas o risco de agir de modo voluntarista acende um pavio de esperança. As cenas coloquiais, na intimidade doméstica, se alternam com os piques de tensão entre os personagens, registros que garantem a fluência do relato e a verossimilhança do drama.

A idade do autor e a restrita experiência de vida se fazem sentir de modo eloquente. O cenário escolhido evidencia o teor das dificuldades enfrentadas por Guarnieri ao lidar com um universo social radicalmente distinto do seu. A peça original se passa num morro do Rio Janeiro, cujo imaginário como reduto do "autenticamente" popular, alimentado pelo cinema novo e pela música, era partilhado também pelo jovem Guarnieri em sua tentativa de recriar nesse ambiente carioca que ele conhecia de esguelha, os personagens populares indispensáveis à trama em torno da greve. O apelo ao pitoresco não fora impensado; a favela era o único reduto sobre cujas feições genéricas o autor se sentia autorizado a discorrer. A linguagem mobilizada pelos personagens destoava, porém, daquela utilizada pelos habitantes do morro que, por sua vez, pareciam um tanto deslocados no enredo de uma greve organizada. Conforme declarações do próprio autor, ele teria insuflado nos personagens da favela retalhos de experiência e impressões pessoais que havia retido de sua vivência de menino com a empregada doméstica na casa dos pais. Por conta dos afazeres profissionais dos pais, ficava todo o tempo em sua companhia, e assim teve a oportunidade de conhecer cortiços e entrar em contato com outras figuras de condição modesta. ${ }^{18}$

Já o filme de Leon Hirzsman, que estreou em 1981 com o mesmo título da peça de Guarnieri, transladou, com acerto, o ambiente da trama para um bairro operário da região paulista do $A B C .{ }^{19}$ Tal decisão revigorou a força do texto, a crueza dos personagens, a ferocidade dos conflitos, ainda mais porque o filme foi rodado logo depois da belicosa greve dos metalúrgicos no $A B C$, em 1979. No filme, quase tudo adquire fortíssima verossimilhança: cenário e figurinos; ${ }^{20}$ a doida e pungente interpretação de Fernanda Montenegro no papel de Romana; ${ }^{21}$ o contraste coreográfico entre a movimentação coletiva do movimento grevista e o caminho individualista trilhado por Tião. O enfrentamento com o regime militar modelou a conduta subsequente do movimento sindical, redefiniu as relações da intelectualidade com os reclamos da classe trabalhadora e impôs novos rumos às negociações entre os principais atores políticos 
naquela conjuntura. No ano da greve, Leon Hirzsman já iniciara a filmagem de um documentário a respeito daquela explosão grevista. ${ }^{22} \mathrm{~A}$ pegada política do filme é incomparável à da peça pelo fato de haver aberto um diálogo escancarado com o caldeirão de conflitos na época. Na virada da década de 1950, a ressonância política da peça incendiou as disposições messiânicas de um público universitário, no apogeu da esperança desenvolvimentista atiçada pelo governo Juscelino. O filme, por sua vez, replicou sem disfarce a resistência de um setor em polvorosa da classe operária.

Embora não tenhamos assistido à montagem de estreia da peça, no Teatro de Arena, podemos imaginar o quão postiço deve ter soado o desempenho de diversos atores na pele de personagens do povo. A maratona de exercícios vocais de Eugenio Kusnet não deve ter driblado o acento forasteiro no papel de Otávio, ${ }^{23}$ dicção que sem dúvida reforçou o feitio stalinista do pai na versão teatral; o pathos transmitido por Lelia Abramo remediou com grandeza a condição humana da figura materna (Romana) sem dar conta do abandono e do desconsolo na condição operária. Os sentimentos de identificação suscitados pelo par romântico vivido por Guarnieri e Miriam Mehler tinham muito mais a ver com a hexis corporal desse casal bem cuidado, gente bonita semelhante a tantos outros na plateia, socialmente plausível, mas inviabilizado no espaço cênico. Não obstante, esses intérpretes - rebentos de famílias de imigrantes italianos e judeus - faziam transbordar em cena a seiva transformadora daquela emergente sociedade paulista. Nas palavras de Sábato Magaldi, espectador e crítico da primeira montagem, "as inadequações dos atores foram sem dúvida superadas pela sinceridade do texto, que os envolveu no seu clima comunicativo" (Magaldi, 1984: 32). Eis algumas evidências que sinalizam a distância quase insuperável entre o mundo da classe operária e o microcosmo culto da classe média urbana em que se situava o autor.

Eles não usam black-tie é o desaguadouro de tudo que sentia o jovem autor, a súmula de experiências de militância, familiar e pessoal, os horizontes e valores da utopia política que norteava a conduta daquela geração de artistas de esquerda. ${ }^{24} \mathrm{O}$ personagem do filho (Tião) condensa, de fato, os dilemas e impasses com que então se defrontavam o autor e seus pares. A peça-síntese da visão de mundo de esquerda constitui o autorretrato de sua experiência pessoal, do itinerário convulsivo daquela geração de dramaturgos, encenadores e atores. Diríamos mesmo que o espetacular sucesso da peça e do espetáculo se deveu muito ao transe emotivo que desencadeou na plateia. O imaginário progressista daquele público de classe média cultivada encontrou no drama operário, e no desenlace inesperado, surpreendente, uma gama de experiências que se prestava de modo ideal como espelho projetivo de suas próprias idiossincrasias e contradições. Havia a simultaneidade de dois experimentos: em cena, uma reconstrução um tanto chapada do mundo social operário; na plateia, o tumulto de emoções desencontradas dos espectadores de coração partido 
entre confortos e sonhos. Essa involuntária viagem memorialística enquadrou o recado nas coordenadas da ortodoxia doutrinária e deixou vazar o desarranjo existencial e afetivo na modelagem de Tião, alter ego do dramaturgo. Não fora o escape emocionante proporcionado pela conduta de Tião, o rendimento dramático do texto teria se esvaziado. A ortodoxia doutrinária teria prevalecido sobre os desvãos do psiquismo.

Embora o autor não conhecesse de perto as circunstâncias de vida e trabalho da classe operária naquele ciclo modernizante do país, a peça empreende um resgate mítico oscilante entre o que poderia e o que deveria ser essa experiência de desdita social. Poder-se-ia sobrepor à narrativa em cena uma toada em surdina dos impasses com que estava se defrontando toda uma geração de intelectuais e artistas, originários de famílias de classe média ilustrada. Esses jovens entusiastas, cem por cento politizados, se viram de repente balançados entre os privilégios de classe e as incitações ao engajamento consequente em que haviam sido educados. A peça de estreia de Guarnieri é uma oportunidade de baldeação entre os imperativos de reprodução corporativa de herdeiros talentosos e os devaneios progressistas em prol de um mundo social justo e equânime. Guarnieri e Vianinha enxergavam o teatro a serviço da causa popular - como instrumento de luta social e ideológica; na falta de um público operário, saturaram de política uma dramaturgia endereçada a uma audiência universitária, de jeans, camisetas coloridas, casacos e botas de couro, ${ }^{25}$ cúmplice do habitus vigente de esquerda. A indumentária urbana da mocidade acabou incorporada às roupas de cena.

\section{EPÍLOGO}

A dramaturgia de Gianfrancesco Guarnieri e de Jorge Andrade sintetiza representações inquietantes de uma sociedade em fogo morto sobre a qual sobrevém a lufada de energias impulsionadas pelos grupos emergentes. Enquanto o "quatrocentão" Andrade remexe as feridas dos abastados de ontem, o "italianinho" Guarnieri fabrica uma classe operária povoada pelo ideário dos setores médios em ascensão. A derrocada da economia cafeeira engolfou proprietários, linhagens, estilos de vida, critérios de prestígio, valores e certezas; a gênese da metrópole fabril carecia de mão de obra qualificada, de consumidores, de novas entidades corporativas, de enfrentamentos e utopias. A cena teatral paulistana abrigava o adeus à civilização do café e a exaltação da sociedade urbano-industrial. 
Heloisa Pontes é professora do Departamento de Antropologia da Universidade Estadual de Campinas (Unicamp), pesquisadora do Pagu - Núcleo de Estudos de Gênero/Unicamp e bolsista de produtividade em pesquisa do CNPq. É autora de Intérpretes da metrópole (2010, prêmio Anpocs de melhor obra científica, atribuído em 2011);

Destinos mistos (1998, prêmio Anpocs/CNPq de melhor obra científica, concedido em 2000); e de diversos artigos publicados em livros e revistas científicas.

Sergio Miceli é professor titular de Sociologia na Universidade de São Paulo (USP), com especialização em sociologia dos intelectuais, sociologia da arte e da cultura. É autor, entre outros, de Vanguardas em retrocesso: ensaios de história social e intelectual do modernismo latino-americano (2012), e de Ensayos porteños: Borges, el nacionalismo y las vanguardias (2012). 


\section{NOTAS}

1 A esse respeito, ver Ridenti (2000), Schwarz (1978) e Napolitano (2001).

2 Apreendidas em sua diversidade histórica, sociológica e etnográfica, as casas, como mostra Janet Carsten, têm um enorme poder de evocação em virtude das conexões que ligam o que acontece dentro delas - hábitos alimentares partilhados em meio às relações altamente emotivas do parentesco -, às práticas corporais repetidas que, pelo efeito do habitus, se transformam numa espécie de segunda natureza. Perpassadas por relações de intimidade, as casas "fazem o parentesco" e, por extensão, "as pessoas e os corpos", na formulação instigante da Janet Carsten (2000: 3156). Permeadas por significados políticos mais amplos, as casas são microcosmos do mundo social, como mostra Bourdieu em relação à casa Kabila, que replica em seus espaços internos as distinções sociais e de gênero e se "organiza com as mesmas homologias que ordenam todo o universo social" (2002: 96). Para um desenvolvimento do potencial analítico envolvido no estudo do parentesco a partir do que acontece dentro das casas, ver Lévi-Strauss (1986). Para uma análise densa das conexões entre casas, estrutura social, simbolismo e hierarquia, ver Elias (2001) e Marcelin (1999).

3 Para uma análise da relação entre cidade, teatro, público e sociedade, ver Charle (2008) e Pontes (2012).

4 As dez peças que compõem a obra de Jorge Andrade foram reunidas no livro Marta, a árvore e o relógio (1986).

5 Sobre a obra de Jorge Andrade, cabe destacar a fortuna crítica incluída no livro Marta, a árvore e o relógio (1986) de autoria de intelectuais de prestígio, como Anatol Rosenfeld, Décio de Almeida Prado, Antonio Candido e Sábato Magaldi. Ao reunir a produção teatral de Jorge Andrade, o volume renovou o interesse por sua dramaturgia. Desde então, historiadores e cientistas sociais, ao lado de estudiosos do teatro e da televisão (mídia na qual Jorge Andrade também atuou), têm se debruçado sobre a sua obra. Vale destacar Sant'Anna (1997), Arantes (2001), Arruda (2001) e o dossiê organizado por Maciel (2005). 
6 O delineamento de momentos-chave da biografia de Jorge Andrade não visa aqui comprovar veracidade, e sim sua incidência na memória do autor, tal como circunscrita por ele em Labirinto (2009).

7 Informação obtida em Jorge Andrade, Labirinto (2009: 69).

8 Ver Décio de Almeida Prado (1998: 7). Neste cenário renovado, o Teatro Brasileiro de Comédia correspondeu, na arte dramática, ao que a criação da Faculdade de Filosofia da Universidade de São Paulo fez no plano intelectual.

9 Sobre o círculo de juventude de Décio de Almeida Prado, o Grupo Clima, ver Pontes (1988).

10 Para uma análise detalhada das razões que fizeram com que o TBC e a cidade de São Paulo assumissem essa posição proeminente, ver Brandão (1988) Arruda (2001), Mattos (2002) e Pontes (2010).

11 Definição retirada do Novo dicionário Aurélio da língua portuguesa, 2. ed. revista e ampliada.

$12 \mathrm{Na}$ apresentação do livro, Sábato Magaldi ressalta o fato de que Labirinto embaralha fronteiras rígidas entre gêneros literários, apresenta um texto sólido, vigoroso e emocionante, "busca do tempo perdido [do autor], como de todos nós", funcionando como "um imenso prefácio de Marta, a árvore e o relógio".

13 A respeito do Teatro de Arena, consultar Magaldi (1984), Almada (2004), Roveri (2004) e a revista Dionysos (1978).

14 Ver entrevista com José Renato (1982: 75-118).

15 A respeito das temporadas italianas de ópera no Teatro Municipal carioca, do início do século XX até 1936, consultar Miceli (2003). A maioria das feições aí analisadas continuava vigente na meninice de Gianfrancesco na década de 1940.

16 Ver as memórias de Deocélia Vianna, Companheiros de viagem (1984).

17 Vianinha estreou como autor no Teatro de Arena, em 1959, com as peças Chapetuba Futebol Clube e Bilbao, via Copacabana.

18 Ver o depoimento de Guarnieri sobre a empregada faz-tudo Margarida na entrevista concedida ao programa Roda-Viva, São Paulo, Televisão Cultura, em agosto de 1991, disponível em DVD, e no livro citado de Sergio Roveri (2004: 24). 
19 Leon Hirzsman, Eles não usam black-tie, 1981, 35 mm, 134 minutos.

20 Enquanto a peça se passa inteira num barraco de morro, o filme alterna tomadas no interior da casa operária a cenas externas, ora envolvendo os grevistas e a repressão, ora a conversa amorosa de Tião e Maria na rua, ora o rompimento final entre pai e filho no terreno da casa.

21 Sobre a origem popular de Fernanda Montenegro e os efeitos reflexivos dessa experiência em seu trabalho em cena, ver Pontes (2011: 304-305). Tornou-se emblemática do filme a cena final em que Fernanda está sentada separando feijão.

22 Leon Hirzsman, Abc da greve, São Paulo, 1979-1990, cor, não ficção, $16 \mathrm{~mm}$, 89 minutos.

23 "O Eugenio Kusnet pediu para que fossem gravadas as falas do Otávio [...] que era seu personagem [...]. Ele tinha um sotaque muito acentuado, então ficava horas ouvindo aquelas fitas para compreender como deveriam ser as falas do Otávio” (Roveri, 2004: 90).

24 "Eu coloquei no personagem Tião as dúvidas que eram minhas [...] era um personagem que pensava muito nele e, para que ele não fosse odiado, coloquei muitas virtudes em sua personalidade. Acho que ao rechear o Tião de coisas tão positivas, eu estava tentando defendê-lo. E com isso, tentando me defender também [...]. Eu nunca admitia para mim mesmo que eu pudesse estar no lugar do Tião..." (Roveri, 2004: 86-88).

$25 \mathrm{Na}$ montagem de Arena conta Zumbi, o grupo acatou a sugestão do figurinista Flávio Império para que atores e atrizes usassem jeans, camisetas e botas de couro, segundo a entrevista concedida por David José transcrita em Almada (2004: 115). 


\section{REFERÊNCIAS BIBLIOGRÁFICAS}

Almada, Izaías. Teatro de Arena. São Paulo: Boitempo, 2004. Andrade, Jorge. Labirinto. Barueri: Manole, 2009. . Marta, a árvore e o relógio. 2.ed. ampliada. São Paulo: Perspectiva, 1986.

Arantes, Luís Martins. Teatro da memória. São Paulo: Anablume/Fapesp, 2001.

Arruda, Maria Arminda do Nascimento. Metrópole e cultura. São Paulo no meio século XX. Bauru: Edusc, 2001.

Bourdieu, Pierre. A casa ou o mundo às avessas. In: Corrêa, Mariza (org.). Ensaios sobre a África do Norte. Texto Didático, [1969] 2002.

Brandão, Tânia. Peripécias modernas: Companhia Maria Della Costa. Tese de doutorado. IFCS/Universidade Federal do Rio de Janeiro, 1988, 2 vols.

Carsten, Janet. After kinship. Nova York: Cambridge University Press, 2000.

Charle, Christophe. Théâtres en capitales. Paris: Éditions Albin Michel, 2008.

Dionysos, 1978, 24 (número especial dedicado ao Teatro de Arena). Rio de Janeiro: MEC-DAC-FUNARTE-SNT.

Elias, Norbert. A sociedade de corte. Rio de Janeiro: Zahar, [1938] 2001.

Guarnieri, Gianfrancesco. Eles não usam black-tie. 12. ed. Rio de Janeiro: Civilização Brasileira, 2001.

Guzik, Alberto. TBC: crônica de um sonho. São Paulo: Perspectiva, 1986.

Lévi-Strauss, Claude. A noção de casa. In: Minhas palauras. São Paulo: Brasiliense, 1986.

Maciel, Diógenes Vieira (org.). Dossiê em homenagem a Jorge Andrade. Fênix-Revista de História e Estudos Culturais, 2005, 2/4.

Magaldi, Sábato. Consciência privilegiada do teatro. In: Prado, Décio de Almeida, Apresentação do teatro moderno brasileiro. São Paulo: Perspectiva, 2002, p. ix-xv.

Um painel histórico: o teatro de Jorge Andrade. In: Andrade, Jorge. Marta, a árvore e o relógio. 2. ed. São Paulo: Perspectiva, 1986, p. 672-683. 
. Dos bens ao sangue. In: Andrade, Jorge. Marta, a árvore e o relógio. 2. ed. São Paulo: Perspectiva, 1986, p. 648-652.

. Um palco brasileiro, o Arena de São Paulo. São Paulo: Brasiliense, 1984.

Marcelin, Louis. A linguagem da casa entre os negros no recôncavo baiano. Mana, 1999, 5/2, p. 31-60.

Mattos, Davi José. O espetáculo da cultura paulista. São Paulo: Códex, 2002.

Mello e Souza, Gilda de Exercícios de leitura. São Paulo: Duas Cidades, 1980.

Miceli, Sergio. Entre o palco e a televisão. In: Santos, Wanderley G. dos (org.). Estatísticas do Século XX. Rio de Janeiro: IBGE, 2003, p. 275-330.

Montenegro, Fernanda. Viagem ao outro: sobre a arte do ator. Rio de Janeiro: Fundacen, 1998.

Morse, Richard. Mito urbano e realidade. In: Andrade, Jorge. Marta, a árvore e o relógio. 2. ed. São Paulo: Perspectiva, 1986, p. 645-647.

Napolitano, Marcos. A arte engajada e seus públicos, 19551968. Estudos Históricos, 2001, 28.

Pontes, Heloisa. Introdução à edição brasileira. Sociedade em cena. In: Charle, Christophe, A gênese da sociedade do espetáculo. São Paulo: Companhia das Letras, 2012, p. 9-18. . Intérpretes da metrópole. São Paulo: Edusp/Fapesp,2010. . Destinos mistos. São Paulo: Companhia das Letras, 1998. Prado, Décio de Almeida (org.). Gianfrancesco Guarnieri, o melhor teatro. São Paulo: Global, 2001, p. 19-87.

. Teatro Brasileiro de Comedia revê os seus 50 anos". O Estado de S. Paulo, 10 out. 1998, p. 7.

. A moratória. In: Andrade, Jorge. Marta, a árvore e o relógio. 2. ed. São Paulo: Perspectiva, 1986, p. 625-629.

Raulino, Berenice. Ruggero Jacobbi. São Paulo: Perspectiva/ Fapesp, 2002.

Renato, José. Depoimentos VI. Rio de Janeiro: Ministério da Educação e Cultura/Secretaria da Cultura, Serviço Nacional do Teatro, 1982, p. 75/118.

Ridenti, Marcelo. Em busca do povo brasileiro. Rio de Janeiro: Record, 2000. 
Roveri, Sérgio. Gianfrancesco Guarnieri, um grito solto no ar. São Paulo: Imprensa Oficial, coleção Aplauso, 2004.

Sant'Anna, Catarina. Metalinguagem e teatro. Cuiabá: Ed. UFMT, 1997.

Schorske, Carl. Viena fin-de-siècle. São Paulo: Companhia das Letras, 1993.

Schwartz, Roberto. O pai de família e outros estudos. Rio de Janeiro: Paz e Terra, 1978.

Tolstói, Liev. Anna Kariênina. São Paulo: Cosac Naify, [1878] 2009.

Vianna, Deocélia. Companheiros de viagem. São Paulo: Brasiliense, 1984.

Yates, Frances A. A arte da memória. Campinas: Ed. Unicamp, 2007. 


\section{Resumo:}

Memória e utopia, transmutadas em linguagem teatral, renovam a apreensão da relação entre dramaturgia e experiência social. Em A moratória (1955) e Rastro atrás (1966), a lembrança do descenso da família de Jorge Andrade impregna a fala dos personagens e dos objetos que os cercam. Neles se inscreve a história da família e da oligarquia agrária a que pertenceu o dramaturgo. A peça de Gianfrancesco Guarnieri, Eles não usam black-tie (1958), ativou os sonhos de uma geração sobre o potencial da cultura na reordenação da sociedade. O operariado estreou nos palcos da metrópole pelo drama de uma família tensionada pela greve, pelo conflito geracional e pela luta de classes. Eis a prova do relevo da cena teatral numa conjuntura excepcional de transformação da cultura brasileira, sinalizada pelo cinema novo e pelo intrincado entrelaçamento do teatro, com o rádio e com o início da televisão no país.

\section{Abstract:}

Memory and utopia translated into theatrical language renew the apprehension of the relationship between drama and social experience. In "A moratoria" (1955) and "Rastro atrás" (1966), the remembrance of Jorde Andrade's family decline nurtures the characters sayings and the objects surrounding them, a sample of the family and of the rural class history to which he belonged. Gianfrancesco Guarnieri's "Eles não usam black-tie" (1958) woke up the dreams of the young generation towards the potential of culture's contribution to a better society. The working class protagonists performed for the first time in the metropolis' stages through a family drama overwhelmed by the strike, the generational conflict and the class struggle. All this higlights the decisive role of the theatre in a changing moment of Brazilian culture, besides the rise of "cinema novo", proving the connection between the theatre, the radio and the beginning of television in the country.

\section{Palavras-chave:}

Dramaturgia e experiência social; Memória e utopia; Arte e sociedade; Jorge Andrade; Gianfrancesco Guarnieri.

\section{Keywords:}

Drama and social experience; Memory and utopia; Art and society; Jorge Andrade; Gianfranceso Guarnieri. 